\title{
A VIOLAÇÃO DO DIREITO FUNDAMENTAL À RAZOÁVEL DURAÇÃO DO PROCESSO COMO HIPÓTESE DE DANO MORAL
}

\author{
THE VIOLATION OF THE FUNDAMENTAL RIGHT TO \\ REASONABLE DURATION OF THE PROCESS \\ AS HYPOTHESIS OF MORAL DAMAGE
}

\author{
MARCELO VEIGA FRANCO ${ }^{1}$
}

\begin{abstract}
RESUMO: O presente artigo tem como objetivo propor a violação do direito fundamental à razoável duração do processo como hipótese de dano moral. Para tanto, em um primeiro momento, são analisados a efetividade do processo e o acesso à ordem jurídica justa, em correlação com a garantia da proteção judicial dentro de um prazo razoável. Posteriormente, é definida a razoável duração do processo como um direito fundamental, o qual está conjugado com as demais garantias constitucionais do processo. Ao final, é estudado o problema da intempestividade processual, com a conclusão de que há a possibilidade de configuração de dano moral ao jurisdicionado na hipótese de violação à garantia fundamental da razoável duração do processo.

PALAVRAS-CHAVE: Efetividade do Processo; Razoável Duração do Processo; Dano Moral.
\end{abstract}

ABSTRACT: This article aims to propose the violation of the fundamental right to reasonable duration of the process as hypothesis of moral damage. To do so, at first, we analyze the effectiveness of the process and the access to a fair legal system, in correlation with the guarantee of legal protection within a reasonable time. Subsequently, we define the reasonable duration of the process as a fundamental right, which is combined with the other constitutional guarantees of the process. Finally, we study the problem of processing delays, with the conclusion that there is the possibility of setting moral damage in cases of violation of the fundamental guarantee of reasonable duration of the process.

KEYWORDS: Effectiveness of the Process; Reasonable Duration of Process; Moral Damage.

Artigo recebido em 01.01.2013. Pareceres emitidos em 23.01.2013 e 15.03.2013.

Artigo aceito para publicação em 23.06.2013.

${ }^{1}$ Mestre em Direito Processual Civil pela Universidade Federal de Minas Gerais (UFMG). Procurador do Município de Belo Horizonte/MG. Advogado.veigafranco@hotmail.com 
SUMÁRIO: 1. A Efetividade do Processo e o Acesso à Ordem Jurídica Justa: A garantia da proteção judicial dentro de um prazo razoável; 2. A Razoável Duração do Processo como Direito Fundamental; 2.1 Razoável Duração do Processo não se Confunde com Celeridade a todo Custo: A necessária conciliação com o contraditório, a ampla defesa e a segurança jurídica; 3. O Problema da Intempestividade Processual e a Possibilidade de Configuração de Dano Moral ao Jurisdicionado; Considerações Finais; Referências Bibliográficas.

SUMMARY: 1. The Effectiveness of the Process and the Access to a Fair Legal System: The guarantee of legal protection within a reasonable time; 2. The Reasonable Duration of the Process as a Fundamental Right; 2.1 The Reasonable Duration of the Process should not be Confused with Speed at all Costs: The necessary conciliation with the adversary, the broad defense and the legal certainty; 3 . The Problem of Processing Delays and the Possibility of Setting Moral Damage; Final Remarks; References.

\section{A EFETIVIDADE DO PROCESSO E O ACESSO À ORDEM JURÍDICA JUSTA: A GARANTIA DA PROTEÇÃO JUDICIAL DENTRO DE UM PRAZO RAZOÁVEL}

A busca pela efetividade processual e pela ampliação do acesso à justiça constituem preocupações recorrentes em um Estado Democrático de Direito. A obtenção de uma prestação jurisdicional dentro de um prazo razoável (art. $5^{\circ}$, LXXVIII, da CRFB), que seja acessível a todas as camadas da população, é essencial para que seja realizada a tutela do direito material de modo adequado.

Nessa ordem de ideias, é necessário que se assegure uma pronta resposta jurisdicional que seja capaz de materializar a principal função do processo de "efetiva realização dos direitos". ${ }^{2}$ A pacificação social demanda que o processo atue como instrumento de satisfação do direito substancial e de materialização das garantias constitucionais, ${ }^{3}$ pois "é pelo processo que se assegura a concretização e a conservação dos direitos fundamentais". Entrementes, o princípio constitucional da inafastabilidade da jurisdição permite que haja a garantia da proteção judicial contra ameaças ou lesões às esferas jurídicas dos cidadãos (art. $5^{\circ}, \mathrm{XXXV}$, da CRFB). ${ }^{5}$

Com isso, a atribuição de efetividade à tutela jurisdicional resulta na superação da ideia do processo como forma, e pela forma. A partir de uma perspectiva substancial da instrumentalidade processual - que ultrapassa uma visão meramente nominal ou formal -, o processo se torna apto a efetivamente implicar transformações e resultados práticos na realidade social. ${ }^{6}$

\footnotetext{
${ }^{2}$ WATANABE, Kazuo. Da Cognição no Processo Civil. 2. ed., Campinas: Bookseller, 2000, p. 19.

3 OLIVEIRA, Carlos Alberto Alvaro de. Teoria e Prática da Tutela Jurisdicional. Rio de Janeiro: Forense, 2008, p. 92-93.

${ }^{4}$ CASAGRANDE, Érico Vinícius Prado. Efetividade do Direito e Eficiência do Judiciário. In: TAVARES, Fernando Horta (Coord.). Urgências de Tutela. Curitiba: Juruá, 2007, p. 82.

${ }^{5}$ THEODORO JUNIOR, Humberto. Celeridade e Efetividade da Prestação Jurisdicional: Insuficiência da reforma das leis processuais. Revista de Processo, São Paulo, ano 30, n 125, p. 63, jul. 2005.

${ }^{6}$ DINAMARCO, Cândido Rangel. Instituições de Direito Processual Civil. 6. ed., São Paulo: Malheiros, 2009. v. 1, p. 110-112.
} 
Com efeito, José Carlos Barbosa Moreira enumera cinco itens que retratam um "programa básico" da efetividade processual, a saber: a) o processo deve dispor de instrumentos adequados de tutela a todos os direitos; b) esses instrumentos devem ser praticamente utilizáveis; c) é preciso assegurar condições propícias à completa restituição dos fatos relevantes, a fim de que o convencimento do julgador corresponda à realidade; d) o resultado do processo deve assegurar à parte vitoriosa o gozo pleno da específica utilidade a que faz jus; e) é preciso atingir o resultado prático com o mínimo dispêndio de tempo e de energia.?

Já Carlos Alberto Alvaro de Oliveira aduz que o "princípio da efetividade impõe a superação de modelos ultrapassados de tutela jurisdicional para certas situações lesivas ao direito material, em prol de mais eficaz e rápida realização do direito material". ${ }^{8}$ José Roberto Bedaque entende que é necessário definir o processo como um "instrumento cuja utilidade é medida em função dos benefícios que possa trazer para o titular de um interesse protegido pelo ordenamento jurídico material"."

Destarte, o processo, para que seja efetivo, deve constituir em instrumento que seja apto "a proporcionar precisamente aquilo que o cumprimento de uma obrigação ou obediência ao dever proporcionaria se não tivesse havido ilícito algum". ${ }^{10}$ A efetividade processual se destina à produção de resultados semelhantes àqueles gerados por meio do cumprimento espontâneo das normas jurídicas.

Dentro desse enfoque, a efetividade do processo possui extrema relevância justamente porque viabiliza a satisfação do direito material, a realização dos direitos fundamentais e a concreção das garantias processuais. ${ }^{11} \mathrm{~A}$ ideia da instrumentalidade processual ${ }^{12}$ é conjugada com a necessidade de respeito ao devido processo legal, aos direitos fundamentais e às garantias constitucionais do processo. ${ }^{13}$

\footnotetext{
${ }^{7}$ MOREIRA, José Carlos Barbosa. Temas de Direito Processual: sexta série. São Paulo: Saraiva, 1991, p. 17-18.

${ }^{8}$ OLIVEIRA, Carlos Alberto Alvaro de. Efetividade e Tutela Jurisdicional. In: MARINONI, Luiz Guilherme (Coord.). Estudos de Direito Processual Civil: homenagem ao professor Egas Dirceu Moniz de Aragão. São Paulo: Revista dos Tribunais, 2006, p. 438.

${ }^{9}$ BEDAQUE, José Roberto dos Santos. Direito e Processo: influência do direito material sobre o processo. 5. ed., São Paulo: Malheiros, 2009, p. 14-15.

${ }_{10}$ WAMBIER, Teresa Arruda Alvim. Aspectos Polêmicos da Antecipação da Tutela. São Paulo: Revista dos Tribunais, 1997, p. 206-209.

${ }^{11}$ BEDAQUE, José Roberto dos Santos. Efetividade do Processo e Técnica Processual. 3. ed., São Paulo: Malheiros, 2010, p. 80.

${ }_{12}$ DINAMARCO, Cândido Rangel. A Instrumentalidade do Processo. 14. ed., São Paulo: Malheiros, 2009.

${ }^{13}$ THEODORO JUNIOR, Humberto. O Processo Civil Brasileiro no Limiar do novo Século. Rio de Janeiro: Forense, 1999, p. 02, destaques no original; em sentido semelhante: ANDRADE, Érico. O Mandado de Segurança: a busca da verdadeira especialidade (proposta de releitura à luz da efetividade do processo). Rio de Janeiro: Lumen Juris, 2010, p. 135-136.
} 
De tal sorte, a efetividade do processo possibilita a materialização de uma tutela jurisdicional adequada e tempestiva, hábil a realizar o direito material subjetivo por intermédio de um devido processo legal assecuratório das garantias constitucionais processuais, e cujo trâmite temporal se desenvolva em um prazo com razoável duração. Na luta pela efetividade da jurisdição, busca-se que "o vencedor da demanda obtenha o bem da vida pleiteado no processo em um período de tempo razoável". ${ }^{14}$

Paralelamente, a efetividade do processo guarda estreita relação com a garantia fundamental do acesso à justiça, de modo que a duração razoável do processo se apresenta como um desdobramento do princípio constitucional da inafastabilidade da jurisdição (art. $5^{\circ}, X X X V$, da CRFB). ${ }^{15}$

A moderna concepção do princípio da inafastabilidade da jurisdição ultrapassa a ideia de garantia formal do cidadão de provocar o Judiciário e de ingressar em juízo (direito público subjetivo de invocar a prestação jurisdicional), ${ }^{16}$ para consubstanciar o acesso à ordem jurídica justa, ${ }^{17}$ o qual resulta em uma tutela jurisdicional efetiva, sem dilações excessivas ou formalismos desnecessários, enfim, tempestiva, adequada e qualificada contra qualquer forma de denegação de justiça. ${ }^{18}$

De fato, o cidadão, no Estado Democrático de Direito, possui o direito fundamental à tutela jurisdicional efetiva. O jurisdicionado goza da garantia constitucional de que terá efetividade na proteção judicial de sua esfera jurídica, por meio de um processo desenvolvido sem dilações indevidas, em face do dever do Estado de tutela dos direitos ameaçados ou lesados. ${ }^{19}$

\footnotetext{
${ }^{14}$ ROCHA, Cesar Asfor. A Luta pela Efetividade da Jurisdição. São Paulo: Revista dos Tribunais, 2008 , p. 39.

${ }^{15}$ WAMBIER, Luiz Rodrigues; WAMBIER, Teresa Arruda Alvim; MEDINA, José Miguel Garcia. Breves Comentários à Nova Sistemática Processual Civil. 3. ed., São Paulo: Revista dos Tribunais, 2005, p. 27.

${ }^{16}$ TUCCI, Rogério Lauria; TUCCI, José Rogério Cruz e. Constituição de 1988 e Processo: Regramentos e garantias constitucionais do processo. São Paulo: Saraiva, 1989, p. 10.

17 Segundo Kazuo Watanabe, os dados elementares do direito à ordem jurídica justa são: a) o direito à informação; b) o direito à adequação entre a ordem jurídica e a realidade socioeconômica do país; c) o direito ao acesso a uma Justiça adequadamente organizada e formada por juízes inseridos na realidade social e comprometidos com o objetivo de uma prestação jurisdicional justa; d) o direito a preordenação dos instrumentos processuais capazes de promover a tutela objetiva dos direitos; e) o direito à remoção dos obstáculos que se anteponham ao acesso efetivo a uma Justiça que tenha tais características. (WATANABE, Kazuo. Participação e Processo. São Paulo: Revista dos Tribunais, 1988, p. 128).

${ }^{18}$ WATANABE, Kazuo. Da Cognição no Processo Civil. 2. ed., Campinas: Bookseller, 2000, p. 27; OLIVEIRA, Carlos Alberto Alvaro de. Do Formalismo no Processo Civil. 2. ed., São Paulo: Saraiva, 2003, p. 271; BEDAQUE, José Roberto dos Santos. Direito e Processo: Influência do direito material sobre o processo. 5. ed., São Paulo: Malheiros, 2009, p. 14-16; DINAMARCO, Cândido Rangel. Instituições de Direito Processual Civil. 6. ed., São Paulo: Malheiros, 2009. v. 1, p. 117-119; DIDIER JR., Fredie. Notas sobre a Garantia Constitucional do Acesso à Justiça: O princípio do direito de ação ou da inafastabilidade do Poder Judiciário. Revista de Processo, São Paulo, ano $27, \mathrm{n}^{\circ} 108$, p. 28, out./dez. 2002.

${ }^{19}$ MARINONI, Luiz Guilherme. Técnica Processual e Tutela dos Direitos. São Paulo: Revista dos Tribunais, 2004, p. 84; 146-147; 165 et seq. Para José Garberí Llobregat, o direito de ação
} 
Nesse diapasão, o "direito à efetividade da jurisdição nada mais é do que exigir do Estado uma decisão justa num prazo razoável, pois é repugnante ter que esperar anos e anos para ver concretizado um direito subjetivo violado". ${ }^{20}$ Com isso, o direito de ação se relaciona ao direito à tutela jurisdicional efetiva, "inserindo-se no direito de ação o direito à tempestividade da prestação jurisdicional". ${ }^{21}$

Por conseguinte, a tutela jurisdicional dos direitos assegura uma resposta estatal, em um tempo hábil, no que tange à pretensão deduzida e aos resultados proporcionados pelo processo no âmbito do direito material. ${ }^{22}$ O processo, assim, "tem de se apresentar como instrumento capaz de propiciar efetividade à garantia de 'acesso à Justiça', ${ }^{23}$ As garantias constitucionais do acesso à justiça e do devido processo legal determinam que "seja assegurada a efetividade real do 'resultado'", o que significa "a possibilidade de obter uma eficaz tutela jurisdicional" em um prazo razoável, destinada à proteção das necessidades do direito substancial. ${ }^{24}$

Outrossim, o cidadão possui o direito fundamental à tutela jurisdicional adequada. Por conseguinte, a proteção judicial dos direitos deve ser proporcional à justa composição do litígio, exercida em tempo razoável e acessível a toda a população. ${ }^{25}$

Portanto, o acesso à ordem jurídica justa requer uma tutela jurisdicional efetiva e adequada, seja quanto à sua tempestividade (duração razoável), seja quanto aos seus resultados (satisfação do direito material), sempre com respeito às garantias fundamentais do processo, especialmente as do contraditório, da ampla defesa, da motivação decisória e do juízo natural.

Para Mauro Cappelletti e Bryant Garth, o acesso à justiça é "o requisito fundamental - o mais básico dos direitos humanos - de um sistema jurídico

compreende o "direito subjetivo público dirigido frente ao Estado a fim de que este preste a tutela jurisdicional sobre os direitos e interesses em conflito" (LLOBREGAT, José Garberí. El Derecho a la Tutela Judicial Efectiva en la Jurisprudencia del Tribunal Constitucional. Barcelona: Bosch, 2008, p. 18, tradução livre).

${ }^{20}$ FERREIRA, Simone Rodrigues. A Efetividade do Direito Fundamental à Razoável Duração do Processo. Revista $I O B$ de Direito Civil e Processual Civil, Porto Alegre, v. 9, no 53, p. 142 , maio/jun. 2008.

${ }^{21}$ MARINONI, Luiz Guilherme. Direito Fundamental à Duração Razoável do Processo. Revista Jurídica, Porto Alegre, ano 57, n 379, p. 12, maio 2009.

${ }_{22}$ MAGALHÃES, Ana Luíza de Carvalho; CÔRTES, Osmar Mendes Paixão. Efetividade da Prestação Jurisdicional: $O$ inciso LXXVIII, do Art. $5^{\circ}$ da Constituição Federal inserido pela EC 45/2004. Revista de Processo, São Paulo, v. 31, nº 138, p. 85, ago. 2006.

${ }^{23}$ THEODORO JUNIOR, Humberto. Celeridade e Efetividade da Prestação Jurisdicional: Insuficiência da reforma das leis processuais. Revista de Processo, São Paulo, ano 30, no 125, p. 65, jul. 2005.

${ }_{24}$ OLIVEIRA, Carlos Alberto Alvaro de. Teoria e Prática da Tutela Jurisdicional. Rio de Janeiro: Forense, 2008, p. 84-85.

${ }^{25}$ MELO, Gustavo de Medeiros. O Acesso adequado à Justiça na Perspectiva do Justo Processo. Disponível em: http://www.ibds.com.br/artigos/OACESSOADEQUADOaJUSTIcANAPERSPECTIVA DOJUSTOPROCESSO.pdf. Acesso em: 25 jun. 2013. 
moderno e igualitário que pretenda garantir, e não apenas proclamar os direitos de todos". ${ }^{26} \mathrm{O}$ acesso à justiça, como expressão maior da garantia da proteção judicial dos cidadãos contra eventuais abusos, ameaças ou lesões às suas esferas jurídicas, determina duas finalidades básicas de um sistema jurídico pelo qual as pessoas reivindicam direitos e/ou resolvem litígios: "Primeiro, o sistema deve ser igualmente acessível a todos; segundo, ele deve produzir resultados que sejam individual e socialmente justos".

Nessa toada, Fernando Gonzaga Jayme ensina que da efetividade do processo e do acesso à justiça decorre a cláusula da garantia de proteção judicial, a qual está prevista no art. 25 da Convenção Americana de Direitos Humanos (Pacto de São José da Costa Rica):

\section{Artigo $25^{\circ}$ - Proteção judicial}

1. Toda pessoa tem direito a um recurso simples e rápido ou a qualquer outro recurso efetivo, perante os juízes ou tribunais competentes, que a proteja contra atos que violem seus direitos fundamentais reconhecidos pela constituição, pela lei ou pela presente Convenção, mesmo quando tal violação seja cometida por pessoas que estejam atuando no exercício de suas funções oficiais.

2. Os Estados Partes comprometem-se:

a) a assegurar que a autoridade competente prevista pelo sistema legal do Estado decida sobre os direitos de toda pessoa que interpuser tal recurso;

b) a desenvolver as possibilidades de recurso judicial; e

c) a assegurar o cumprimento, pelas autoridades competentes, de toda decisão em que se tenha considerado procedente o recurso.

A garantia de proteção judicial engloba "o direito de acesso à justiça como meio para se obter, em tempo razoável, uma decisão jurisdicional eficaz, quando houver interesse em reparar lesões ou prevenir ameaças a direitos". ${ }^{28}$ É possível, assim, que haja um processo jurisdicional conectado com a realidade social e que produza, dentro de um prazo tolerável, concretas transformações na esfera do direito material.

Em suma, a atribuição de efetividade ao processo (ou melhor, à tutela jurisdicional) e a concretização do acesso a uma ordem jurídica justa, em

\footnotetext{
${ }^{26}$ CAPPELLETTI, Mauro; GARTH, Bryant. Acesso à Justiça. Tradução de Ellen Gracie Northfleet. Porto Alegre: Sergio Antonio Fabris, 1988, p. 12.

${ }^{27}$ CAPPELLETTI, Mauro; GARTH, Bryant. Acesso à Justiça. Tradução de Ellen Gracie Northfleet. Porto Alegre: Sergio Antonio Fabris, 1988, p. 08; CAPPELLETTI, Mauro. Processo, Ideologias e Sociedade. Tradução de Elício de Cresci Sobrinho. Porto Alegre: Sergio Antonio Fabris, 2008. V. 1, p. 383-393.

${ }_{28}$ JAYME, Fernando Gonzaga. Os Problemas da Efetiva garantia de Proteção Judicial perante o Poder Judiciário Brasileiro. In: JAYME, Fernando Gonzaga; FARIA, Juliana Cordeiro de; LAUAR, Maira Terra (Coord.). Processo Civil - Novas Tendências: estudos em homenagem ao Professor Humberto Theodoro Júnior. Belo Horizonte: Del Rey, 2008, p. 243.
} 
sintonia com a garantia de proteção judicial contra ameaças ou lesões a esferas jurídicas, são essenciais para a tutela dos direitos dos cidadãos. Com isso, a necessidade de uma resposta jurisdicional em um prazo razoável se revela como uma garantia fundamental cívica imprescindível à efetiva realização de uma ordem jurídica democrática. ${ }^{29}$

\section{A RAZOÁVEL DURAÇÃO DO PROCESSO COMO DIREITO FUNDAMENTAL}

O direito fundamental à razoável duração do processo (art. $5^{\circ}$, LXXVIII, da CRFB) decorre do direito subjetivo do jurisdicionado a um processo sem dilações indevidas, cuja origem remonta à Convenção Europeia para Salvaguarda dos Direitos do Homem e das Liberdades Fundamentais, subscrita em Roma, na Itália, no dia 04 de novembro de 1950. O art. 6 1 , da referida Convenção prescreve que "Toda pessoa tem direito a que sua causa seja examinada eqüitativamente e publicamente num prazo razoável, por um tribunal independente e imparcial instituído por lei, que decidirá sobre seus direitos e obrigações civis ou sobre o fundamento de qualquer acusação em matéria penal contra ela dirigida".

Inúmeras legislações estrangeiras também tratam do tema:

O art. 24.2 da Constituição Espanhola de 1978 dispõe que "Todos têm direito ao juiz ordinário previamente determinado por lei, à defesa e à assistência de advogado, a ser informado da acusação contra si deduzida, a um processo público sem dilações indevidas e com todas as garantias (...)". Já o art. 2-1 do Código de Processo Civil Português prevê que "A protecção jurídica através dos tribunais implica o direito de obter, em prazo razoável, uma decisão judicial que aprecie, com força de caso julgado, a pretensão regularmente deduzida em juízo, bem como a possibilidade de a fazer executar". O art. 41 da Carta dos Direitos Fundamentais da União Europeia dispõe que "Todas as pessoas têm direito a que os seus assuntos sejam tratados pelas instituições e órgãos da União de forma imparcial, equitativa e num prazo razoável".

Por seu turno, o art. 11, $b$, da Carta Canadense dos Direitos e Liberdades de 1982 preconiza que "Toda pessoa demandada tem o direito de ser julgada dentro de um prazo razoável". Em sentido semelhante, o art. $8^{\circ}$, inciso 1 , da Convenção Americana de Direitos Humanos (Pacto de São José da Costa Rica) estabelece que "Toda pessoa tem direito a ser ouvida, com as devidas garantias e dentro de um prazo razoável, por um juiz ou tribunal competente, independente e imparcial, estabelecido anteriormente por lei, na apuração de

\footnotetext{
29 THEODORO JUNIOR, Humberto. Celeridade e Efetividade da Prestação Jurisdicional: Insuficiência da reforma das leis processuais. Revista de Processo, São Paulo, ano $30, n^{\circ} 125$, p. 63-65, jul. 2005; MARINONI, Luiz Guilherme. Da Teoria da Relação Jurídica Processual ao Processo Civil do Estado Constitucional. Revista dos Tribunais, São Paulo, vol. 852, ano 95, p. 19, out. 2006; MARINONI, Luiz Guilherme. Novas Linhas do Processo Civil. 2. ed., São Paulo: Malheiros, 1996, p. 24.
} 
qualquer acusação penal formulada contra ela, ou para que se determinem seus direitos ou obrigações de natureza civil, trabalhista, fiscal ou de qualquer outra natureza".

Já nos Estados Unidos da América (EUA), a Sexta Emenda à Constituição (1791) prevê cláusula com a exigência de um julgamento rápido (speedy trial), dispondo que "Em todos os processos criminais, o acusado usufruirá do direito a julgamento rápido e público, por um júri imparcial do Estado e distrito onde o crime tiver sido cometido, distrito esse previamente determinado por lei, e de ser informado da natureza e causa da acusação, de ser acareado com as testemunhas de acusação, de fazer comparecer por meios legais testemunhas de defesa e de ser assistido por advogado". ${ }^{30}$

Contudo, é na Itália que a matéria tem regulamentação mais específica. $O$ art. 111 da Constituição Italiana determina que "A jurisdição atua-se mediante o justo processo regulado pela lei. Cada processo desenvolve-se no contraditório entre as partes, em condições de igualdade perante juiz terceiro e imparcial. A lei assegura a razoável duração. (...)".

De acordo com a doutrina jurídica italiana, a ideia do justo processo (giusto processo) abarca a conciliação de todas as garantias processuais, de modo que a razoável duração do processo é concretizada com a devida observância do contraditório, da ampla defesa, da motivação decisória, do direito à prova, dentre outros direitos fundamentais. ${ }^{31}$ De tal sorte, "processo justo e processo moroso são noções incompatíveis e inconciliáveis", pois o "processo devido - constitucionalmente exigido - não pode deixar de transcorrer em prazo razoável". ${ }^{32}$

Todavia, foi na mesma Itália que a morosidade processual se tornou um problema crônico e manifestamente grave, inclusive com a proliferação de

\footnotetext{
${ }^{30}$ REIS, Marcelo Terra. Tempestividade da Prestação Jurisdicional como Direito Fundamental. In: TEIXEIRA, Anderson Vichinkeski; LONGO, Luís Antônio (Coord.). A Constitucionalização do Direito. Porto Alegre: Sérgio Antônio Fabris, 2008, p. 204. Nos EUA, a American Bar Association publicou qual é o tempo tolerável de duração dos processos nos Tribunais ordinários da justiça norteamericana. Confira: a) causas cíveis: a.1) causas cíveis em geral: $90 \%$ devem ser concluídas dentro de 12 meses e os restantes 10\% em 24 meses, em decorrência de circunstâncias excepcionais; a.2) causas cíveis sumárias: devem ser concluídas em 30 dias; a.3) causas envolvendo relações domésticas: 90\% devem ser concluídas em 30 dias, 98\% em 06 meses e 100\% em um ano; b) causas criminais: b.1) crimes graves (felony): a contar da data do fato, $90 \%$ devem ser concluídos em 120 dias, 98\% em 180 dias e 100\% em um ano; b.2) crimes menos graves e contravenções (misdemeanor): 90\% devem ser concluídos em 30 dias e 100\% em 90 dias; b.3) delitos praticados por menores (juvenile): em caso de prisão, deve ser julgado em 24 horas, ou, caso esteja solto o acusado, em 30 dias. (TUCCI, José Rogério Cruz e. Duração Razoável do Processo (art. 50, LXXVIII, da Constituição Federal). In: JAYME, Fernando Gonzaga; FARIA, Juliana Cordeiro de; LAUAR, Maira Terra (Coord.). Processo Civil - Novas Tendências: Estudos em homenagem ao Professor Humberto Theodoro Júnior. Belo Horizonte: Del Rey, 2008, p. 443-445).

${ }^{31}$ COMOGLIO, Luigi Paolo. Etica e Tecnica del 'giusto Processo'. Torino, G. Giappichelli: 2004, p. 162.

${ }_{32}$ ARRUDA, Samuel Miranda. O Direito Fundamental à Razoável Duração do Processo. Brasília: Brasília Jurídica, 2006, p. 90.
} 
ações judiciais envolvendo pedidos de indenizações em virtude da excessiva lentidão na tramitação de processos. Nesse cenário, a pressão política e popular exercida em face do Estado Italiano culminou em mudanças legislativas importantes.

A primeira delas ocorreu em 23 de novembro de 1999, com a inserção expressa, no art. 111 da Constituição Italiana, da garantia da duração razoável na ideia do justo processo. Posteriormente, em 24 de março de 2001, foi editada a Lei $n^{\circ} 89$, conhecida como Legge Pinto (uma vez que fora de autoria do deputado Michele Pinto), a qual estabeleceu na legislação daquele país a possibilidade de fixação de indenização em virtude de danos sofridos por força de excessiva e desproporcional demora na prestação jurisdicional:

Art. 2. Direito à justa reparação.

1. Quem sofreu um dano patrimonial ou não patrimonial decorrente da violação da Convenção para Salvaguarda dos Direitos do Homem e das Liberdades Fundamentais, ratificada nos termos da lei de 4 de agosto de 1955, no 848, sob a alegação de desrespeito do prazo razoável, assegurado no art. $6^{\circ}, 1$, da Convenção, tem direito a uma justa reparação. ${ }^{33}$

Por sua vez, no Brasil, o direito subjetivo a um processo sem dilações indevidas ganhou inscrição constitucional por meio da promulgação do inciso LXXVIII, do art. $5^{\circ}$, da CRFB, ${ }^{34}$ o qual prevê que "a todos, no âmbito judicial e administrativo, são assegurados a razoável duração do processo e os meios que garantam a celeridade de sua tramitação". ${ }^{35}$

Também o art. 20 do Código de Ética da Magistratura preconiza que "Cumpre ao magistrado velar para que os atos processuais se celebrem com a máxima pontualidade e para que os processos a seu cargo sejam solucionados em um prazo razoável, reprimindo toda e qualquer iniciativa dilatória ou atentatória à boa-fé processual". De maneira semelhante, os incisos II e III do art. 35 da Lei Complementar n 35/1979 (Lei Orgânica da

\footnotetext{
${ }^{33}$ TUCCI, José Rogério Cruz e. Sobre a Duração Razoável do Processo na Europa Comunitária. In: JAYME, Fernando Gonzaga; FARIA, Juliana Cordeiro de; LAUAR, Maira Terra (Coord.). Processo Civil - Novas Tendências: homenagem ao Ministro Sálvio de Figueiredo Teixeira. Belo Horizonte: Del Rey, 2011, p. 478-479.

${ }^{34} \mathrm{Na}$ história do constitucionalismo nacional, já houve, antes do advento da Emenda Constitucional $n^{\circ}$ 45/2004 - a qual acrescentou o inciso LXXVIII ao art. $5^{\circ}$ da Constituição Federal de 1988 -, previsão constitucional contrária à morosidade processual. $\mathrm{O}$ art. 113 , alínea 35 , da Constituição Federal de 1934 previa que "a lei assegurará o rápido andamento dos processos nas repartições públicas (...)". (Disponível em: http://www2.camara.leg.br/legin/fed/consti/1930-1939/constituicao1934-16-julho-1934-365196-publicacaooriginal-1-pl.html. Acesso em: 04 fev. 2013).

${ }^{35} \mathrm{O}$ inciso LXXVIII, do art. $5^{\circ}$, da CRFB "antevê a existência de 'meios' para assegurar a qualquer processo uma 'duração razoável'”. Esses meios podem ser humanos e materiais, como também procedimentais ou legais (como é caso, por exemplo, do art. 71 da Lei $n^{0} 10.741 / 03$ - Estatuto do Idoso -, o qual prevê prioridade na tramitação de processos em que figurem como parte ou interveniente pessoa com idade igual ou superior a sessenta anos). (ASSIS, Araken. Duração Razoável do Processo e Reformas da Lei Processual Civil. Revista Jurídica, Porto Alegre, ano 56, no 372 , p. 15-16, out. 2008).
} 
Magistratura Nacional - LOMAN) dispõem que são deveres dos magistrados "não exceder injustificadamente os prazos para sentenciar ou despachar", bem como "determinar as providências necessárias para que os atos processuais se realizem nos prazos legais".

$\mathrm{Na}$ verdade, independentemente de previsão legal ou constitucional, o processo sem dilações indevidas é um direito fundamental do jurisdicionado. Os cidadãos possuem o "direito à tutela jurisdicional dentro de um prazo razoável, decorrente da proibição do non liquet, vale dizer, do dever que têm os agentes do Poder Judiciário de julgar as causas com estrita observância das normas de direito positivo". ${ }^{36}$

Nessa linha de raciocínio, a razoável duração do processo, com a garantia dos meios que assegurem a celeridade de sua tramitação, constitui direito fundamental de aplicação imediata (art. $5^{\circ}, \S 1^{\circ}$, da CRFB), que gera "direito subjetivo para os destinatários, os quais, no caso em apreciação, podem exigir dos juízes e tribunais que façam com que a duração razoável seja cumprida, caso a caso". ${ }^{37}$

A razoável duração do processo, portanto, significa que o trâmite processual deve obedecer a um lapso de tempo aceitável e, por isso, apto a respeitar as liberdades públicas e os direitos e as garantias fundamentais dos jurisdicionados. O processo deve se desenvolver de modo tempestivo, respeitando os prazos legais e "em condições de normalidade dentro do tempo requerido e no qual os interesses litigiosos podem receber pronta satisfação", ${ }^{38}$ com vistas à efetiva realização do direito material.

Como corolário da razoável duração do processo, ${ }^{39}$ o princípio da economia processual dispõe que, em cada processo, economize-se ao máximo tempo, energia e recurso (perspectiva interna), bem como que se previna novo e inútil julgamento em causas já decididas (perspectiva externa). Nesses termos, o direito à duração razoável do processo visa a diminuir o tempo de tramitação e, igualmente, a incentivar e a instituir outros meios menos onerosos de resolução de controvérsias. ${ }^{40}$

Contudo, na prática, é bastante árdua a tarefa de definir o que é um processo sem dilações indevidas, em face da indeterminação semântica da expressão "razoável duração". Genericamente, a doutrina entende que razoável

\footnotetext{
${ }^{36}$ TUCCI, José Rogério Cruz e. Tempo e Processo: Uma análise empírica das repercussões do tempo na fenomenologia processual (civil e penal). São Paulo: Revista dos Tribunais, 1998, p. 67. 37 THEODORO JUNIOR, Humberto. Direito Fundamental à duração Razoável do Processo. Disponível em: http://www.anima-opet.com.br/segunda_edicao/Humberto_Theodoro_Junior.pdf. Acesso em: 17 dez. 2012.

${ }^{38}$ LLORENTE, Francisco Rubio. Derechos Fundamentales y Principios Constitucionales: Doctrina jurisprudencial. Barcelona: Ariel, 1995, p. 328, tradução livre.

${ }_{39}$ TUCCI, José Rogério Cruz e. Garantias Constitucionais da Duração Razoável e da Economia Processual no Projeto do Código de Processo Civil. Revista de processo, São Paulo, ano 36, no 192, p. 200, fev. 2011.

${ }^{40}$ ANDRADE, Érico. O Mandado de Segurança: A busca da verdadeira especialidade (proposta de releitura à luz da efetividade do processo). Rio de Janeiro: Lumen Juris, 2010, p. 43-44.
} 
é a "duração do processo de acordo com o uso racional do tempo processual" pelas partes.

Por outro lado, as dilações indevidas retratam "os atrasos ou delongas que se produzem no processo por inobservância dos prazos estabelecidos, por injustificados prolongamentos das etapas mortas que separam a realização de um ato processual de outro". ${ }^{42}$ Portanto, um processo sem dilações indevidas é aquele cujo trâmite obedece a um lapso de tempo razoável e se desenvolve de modo econômico, de acordo com as particularidades do caso concreto e com estrito respeito aos prazos legais.

\subsection{Razoável Duração do Processo não se Confunde com Celeridade a todo Custo: A necessária conciliação com o contraditório, a ampla defesa e a segurança jurídica}

O direito fundamental à razoável duração do processo não significa que a prestação jurisdicional deve ser necessariamente rápida, mas, sim, que o processo deve demorar o tempo estritamente necessário à solução da contenda, sem dilações indevidas.

É certo que sempre haverá uma demora na marcha processual, como expressão da própria estrutura dialética do processo. ${ }^{43} \mathrm{O}$ que deve ser evitado, portanto, é o prolongamento excessivo e intolerável do andamento processual, o qual impede a prolação de uma decisão final em uma economia razoável de tempo e de recursos. ${ }^{44}$ Como assevera Samuel Miranda Arruda, o "tempo razoável deve ser compreendido como o suficiente a possibilitar um justo julgamento, mas não tão excessivo que dilate de forma desnecessária a tramitação processual", de forma a que seja alcançado "um tempo de tramitação otimizado". ${ }^{45}$

Nessa ordem de ideais, o direito fundamental à razoável duração do processo se vincula à ideia da tempestividade processual, dentro de um enfoque de efetividade da tutela jurisdicional voltada à garantia do acesso à ordem jurídica justa e da satisfação do direito material em um prazo tolerável. ${ }^{46}$

\footnotetext{
${ }^{41}$ MARINONI, Luiz Guilherme. Técnica Processual e Tutela dos Direitos. São Paulo: Revista dos Tribunais, 2004, p. 183.

${ }^{42}$ GARCIA, José Antonio Tomé. Protección Procesal de los Derechos Humanos ante los Tribunales Ordinarios. Madrid: Montecorvo, 1987, p. 119 apud TUCCI, José Rogério Cruz e. Duração Razoável do Processo (art. 5, LXXVIII, da Constituição Federal). In: JAYME, Fernando Gonzaga; FARIA, Juliana Cordeiro de; LAUAR, Maira Terra (Coord.). Processo Civil - Novas Tendências: Estudos em homenagem ao Professor Humberto Theodoro Júnior. Belo Horizonte: Del Rey, 2008, p. 437.

${ }^{43}$ MARINONI, Luiz Guilherme. O Custo e o Tempo do Processo Civil Brasileiro. Revista da Faculdade de Direito da Universidade Federal do Paraná, Curitiba, vol. 37, p. 44-45, 2002.

${ }^{44}$ DIAS, Ronaldo Brêtas de Carvalho. As Reformas do Código de Processo Civil e o Processo Constitucional. In: DIAS, Ronaldo Brêtas; NEPOMUCENO, Luciana Diniz (Coord.). Processo Civil Reformado. Belo Horizonte: Del Rey, 2007, p. 220.

${ }^{45}$ ARRUDA, Samuel Miranda. O Direito Fundamental à Razoável Duração do Processo. Brasília: Brasília Jurídica, 2006, p. 93; 207.

${ }^{46}$ ZAVASCKI, Teori Albino. Antecipação da Tutela. 4. ed., São Paulo: Saraiva, 2005, p. 65.
} 
Com isso, a celeridade processual - entendida como a rapidez incondicional do processo, ao custo inclusive da supressão de direitos fundamentais e garantias processuais - não pode ser elevada a um objetivo absoluto, ou seja, a uma busca a todo custo pela aceleração do processo. ${ }^{47}$ O direito fundamental à duração razoável do processo não traduz "uma urgencialidade na prestação jurisdicional", ${ }^{48}$ tendo em vista que um processo sem dilações indevidas equivale à proteção judicial dos direitos em um tempo adequado, o que não significa, necessariamente, "justiça acelerada" ${ }^{49}$ ou "jurisdição relâmpago".

Nesse diapasão, tempestividade não se confunde com celeridade processual, "até porque prestação jurisdicional em prazo razoável não é o mesmo que prestação jurisdicional célere". ${ }^{51} \mathrm{Em}$ outras palavras, um processo tempestivo - isto é, com razoável duração - "não significa, necessariamente, um processo veloz, mas um processo que deve andar com certa rapidez, de modo que as partes tenham uma prestação jurisdicional em tempo hábil". ${ }^{52}$

A tempestividade processual, logo, está relacionada à garantia de tramitação e conclusão do processo dentro de um prazo razoável, conforme as particularidades do caso concreto e desde que respeitados os outros direitos fundamentais, especialmente os do contraditório e da ampla defesa.

Por outro lado, a ideia da celeridade processual pode adquirir um sentido de imprópria aceleração do procedimento de "proteção jurídica que se traduza em diminuição de garantias processuais e materiais (prazo de recurso, supressão de instâncias excessivas)", o que conduz "a uma justiça pronta mas materialmente injusta". ${ }^{53}$ A busca frenética pela agilidade processual, assim, torna inadequada a temporalidade ${ }^{54}$ da proteção judicial, uma vez que

\footnotetext{
${ }^{47}$ MOREIRA, José Carlos Barbosa. Temas de Direito Processual: sexta série. São Paulo: Saraiva, 1991, p. 21-22.

${ }^{48}$ GOMES, Magno Federici; SOUSA, Isabella Saldanha de. A Efetividade do Processo e a Celeridade do Procedimento sob o Enfoque da Teoria neo-institucionalista. Revista IOB de Direito Civil e Processual Civil, Porto Alegre, v. 9, nº 57, p. 70, jan./fev. 2009.

${ }^{49}$ SOUSA, Michele Faria de. O Procedimento dos Juizados Especiais Cíveis e Efetividade do Processo. In: TAVARES, Fernando Horta (Coord.). Urgências de Tutela. Curitiba: Juruá, 2007, p. 164.

${ }^{50}$ LEAL, Rosemiro Pereira. A Judiciarização do Processo nas Últimas Reformas do CPC Brasileiro. In: DIAS, Ronaldo Brêtas; NEPOMUCENO, Luciana Diniz (Coord.). Processo Civil Reformado. Belo Horizonte: Del Rey, 2007, p. 259.

${ }^{51}$ RODRIGUES, Clóvis Fedrizzi. Direito Fundamental à Duração Razoável do Processo. Revista IOB de Direito Civil e Processual Civil, ano XI, nº 63, p. 84, jan./fev. 2010.

${ }^{52}$ SILVA, José Afonso da. Comentário Contextual à Constituição. São Paulo: Malheiros, 2006, p. 176.

${ }^{53}$ CANOTILHO, J. J. Gomes. Direito Constitucional e Teoria da Constituição. Coimbra: Almedina, 2002 , p. 493.

${ }^{54}$ A ideia da temporalidade adequada é utilizada no estudo de Samuel Miranda Arruda sobre a busca da noção de tempo, e se define como "requisito à legitimidade da decisão" (ARRUDA, Samuel Miranda. O Direito Fundamental à Razoável Duração do Processo. Brasília: Brasília Jurídica, 2006, p. 277 et seq.).
} 
um processo puramente veloz não adquire o condão de tutelar satisfatoriamente as garantias processuais.

Com isso, o direito fundamental à razoável duração do processo não se coaduna com a aceleração do trâmite processual em detrimento das demais garantias processuais constitucionais. A tempestividade não equivale à rapidez processual, pois, diferentemente, contém a "noção de tempo necessário à preservação das demais garantias processuais", ${ }^{55}$ dentro do escopo de concretização do devido processo legal.

O due process of law requer a conciliação da duração razoável do processo com os demais direitos fundamentais, sobretudo os do contraditório e da ampla defesa. Confira o ensinamento de Ronaldo Brêtas Dias:

Porém, é importante ressaltar que a exigência constitucional de se obter a prestação da atividade jurisdicional em tempo útil ou prazo razoável, o que significa adequação temporal da jurisdição, mediante processo sem dilações indevidas, não permite impingir o Estado ao povo a aceleração dos procedimentos pela diminuição das demais garantias processuais constitucionais (...). A restrição de quaisquer dessas garantias processuais constitucionais, sob a justificativa de agilizar ou tornar célere o procedimento, revela-se inconstitucional e antidemocrática, somente servindo para estimular o arbítrio dos juízes, fomentar a insegurança jurídica e escarnecer da garantia fundamental do devido processo legal, em resumo, deslavada e grosseira agressão ao princípio constitucional do Estado Democrático de Direito. ${ }^{56}$

É certo que "a economia e a celeridade do processo não são incompatíveis com as garantias das partes, e a garantia constitucional do contraditório não permite que seja ele violado em nome do rápido andamento do processo". Em outras palavras, uma decisão "não se qualifica como justa apenas pelo critério da rapidez", ${ }^{57}$ pois a justeza também é necessária no processo e, igualmente, na sentença.

Nessa seara, um processo efetivo e adequado ao Estado Democrático de Direito é aquele que, simultaneamente, seja apto a assegurar um trâmite temporal razoável - como expressão da dignidade da pessoa humana e a concretizar os direitos e as garantias fundamentais - como decorrência do postulado da segurança jurídica. À duração razoável do processo conjuga-se

\footnotetext{
${ }^{55}$ ARRUDA, Samuel Miranda. O Direito Fundamental à Razoável Duração do Processo. Brasília: Brasília Jurídica, 2006, p. 19.

${ }^{56}$ DIAS, Ronaldo Brêtas de Carvalho. Direito à Jurisdição Eficiente e Garantia da Razoável Duração do Processo na Reforma do Judiciário. Revista de Processo, São Paulo, ano 30, n 128, p. 166-167, out. 2005; no mesmo sentido: THEODORO JUNIOR, Humberto. Constituição e Processo: Desafios constitucionais da reforma do processo civil no Brasil. In: MACHADO, Felipe Daniel Amorim; CATTONI DE OLIVEIRA, Marcelo Andrade (Coord.). Constituição e Processo: A contribuição do processo ao constitucionalismo democrático brasileiro. Belo Horizonte: Del Rey, 2009, p. 244-245. ${ }^{57}$ GONÇALVES, Aroldo Plínio. Técnica Processual e Teoria do Processo. Rio de Janeiro: Aide, 1992, p. 124-125.
} 
a proteção da segurança jurídica, para que o exercício da prestação jurisdicional não suprima, de forma ilegítima, a amplitude do direito de defesa das partes. ${ }^{58}$

Portanto, é necessária a conquista do ponto de equilíbrio entre a tempestividade processual e a segurança jurídica. ${ }^{59}$ De nada adianta um processo com razoável duração, mas que implique prejuízos ao contraditório; ao mesmo tempo, é indevido um processo que, embora assecuratório da ampla defesa, seja excessivamente lento e acarrete procrastinações infindáveis.

Assim sendo, muitas vezes, a tempestividade processual é mitigada em prol da concretização da ampla defesa, por meio de uma instrução probatória minuciosa. Por outro lado, também é possível que rígidas formalidades legais ou o próprio contraditório tenham que ser abrandados na busca da realização concreta do direito material. ${ }^{60}$

Portanto, quando definimos a razoável duração do processo como um direito fundamental, não estamos defendendo a celeridade a todo custo, tendo em vista a necessidade de proteção das demais garantias processuais, sob o enfoque do princípio constitucional da segurança jurídica. É preciso que os avanços na busca da efetividade da tutela jurisdicional possam ser aproveitados em conjugação com as demais garantias processuais. A conciliação entre a tempestividade processual e a ampla defesa afirma uma tutela jurisdicional condizente com o Estado Democrático de Direito.

\section{O PROBLEMA DA INTEMPESTIVIDADE PROCESSUAL E A POSSIBILIDADE DE CONFIGURAÇÃO DE DANO MORAL AO JURISDICIONADO}

Um dos mais graves problemas que assola o sistema jurídico brasileiro e mundial diz respeito à lentidão no andamento dos processos. A excessiva demora na tramitação processual resulta em nítidos prejuízos à obtenção de

\footnotetext{
${ }^{58}$ BEDAQUE, José Roberto dos Santos. Efetividade do Processo e Técnica Processual. 3. ed., São Paulo: Malheiros, 2010, p. 49; WELSCH, Gisele Mazzoni. A Razoável Duração do Processo (art. 50, LXXVIII, da CF/88) como Garantia Constitucional. In: MOLINARO, Carlos Alberto; MILHORANZA, Mariângela Guerreiro; PORTO, Sérgio Gilberto (Coord.) Constituição, Jurisdição e Processo: Estudos em homenagem aos 55 anos da Revista Jurídica. Porto Alegre: Notadez, 2007, p. 362-363.

${ }^{59}$ MOREIRA, José Carlos Barbosa. Temas de Direito Processual: nona série. São Paulo: Saraiva, 2007, p. 31-32. Nesse contexto, a ideia da calendarização do processo (ou calendário processual) aparece como boa alternativa para a conjugação da tempestividade processual com o princípio constitucional da segurança jurídica. Ao partir da concepção de que cada causa deve receber um tratamento individualizado, a calendarização do processo significa que o juiz, em conjunto com as partes, deve fixar o calendário do processo. Com isso, são previstas, no início do processo, as datas para a prática dos atos processuais de instrução e de apresentação de peças de defesa, bem como o momento da prolação da decisão, de modo a oferecer às partes um prévio planejamento e um prognóstico aproximado de duração do feito. (ANDRADE, Érico. As Novas Perspectivas do Gerenciamento e da 'contratualização' do Processo. In: JAYME, Fernando Gonzaga; FARIA, Juliana Cordeiro de; LAUAR, Maira Terra (Coord.). Processo Civil - Novas Tendências: Homenagem ao Ministro Sálvio de Figueiredo Teixeira. Belo Horizonte: Del Rey, 2011, p. 155-157).

60 THEODORO JUNIOR, Humberto. Curso de Direito Processual Civil: Teoria geral do direito processual civil e processo de conhecimento. 43. ed., Rio de Janeiro: Forense, 2005. v. I, p. 30.
} 
uma prestação jurisdicional de qualidade, o que implica uma desordem jurídico-social comumente denominada de crise judiciária. ${ }^{61}$ Ademais, 0 exagerado retardamento na resolução das controvérsias ocasiona um crescente descrédito e desprestígio social do Judiciário, ${ }^{62}$ tendo em vista que "justiça tardia não é justiça e, sim, denegação de justiça" "injustiça qualificada e manifesta". ${ }^{64}$

Vários fatores são enumerados para explicar as causas da crise judiciária, tais como: alto número de demandas judiciais em tramitação; ajuizamento abundante de ações judiciais com baixíssimo impacto social ou econômico; interposição de recursos com intuito protelatório ou com insignificantes chances de êxito; falhas na legislação processual; precária gestão administrativo-financeira do Judiciário; burocracia excessiva em cartórios judiciais; falta de infraestrutura física e material das repartições públicas; carência e má qualificação de magistrados, de advogados, de serventuários e de auxiliares da Justiça; atraso tecnológico e falta de modernização dos órgãos judiciários; difusão de uma mentalidade cultural voltada à litigiosidade.

Contudo, a par dos motivos acima enumerados, fato é que, em alguns casos, a intolerável lentidão na tramitação processual pode implicar a configuração de dano mora ${ }^{65}$ em desfavor do jurisdicionado.

Não obstante o número excessivo de processos seja uma "causa determinante da dificuldade da prestação jurisdicional em prazo razoável", ${ }^{66}$

\footnotetext{
${ }^{61}$ Sobre a crise judiciária (ou "crise da Justiça"), Araken de Assis anota que "busca-se nela expressar que a prestação jurisdicional prometida pelo Estado, no Brasil e alhures, tarda mais do que o devido, frustrando as expectativas dos interessados" (ASSIS, Araken. Duração Razoável do Processo e Reformas da Lei Processual Civil. Revista Jurídica, Porto Alegre, ano 56, n 372, p. 13, out. 2008).

${ }^{62}$ Para comprovar o crescente desprestígio social do Judiciário, cite-se pesquisa realizada pela Fundação Getúlio Vargas (FGV), na qual o Judiciário aparece em penúltimo lugar no Índice de Confiança na Justiça, em comparação com outras instituições públicas e privadas. De acordo com essa pesquisa, o Judiciário possui $33 \%$ de confiança da população, atrás de instituições como emissoras de televisão (47\%), imprensa (43\%), Polícia (40\%), partidos políticos (37\%) e Congresso Nacional (36\%). O baixo índice de confiança da população no Judiciário é maior apenas que o do Governo Federal (25\%). (Fonte: Índice de Confiança na Justiça/FGV - $4^{\circ}$ trimestre de 2010).

${ }_{63}$ THEODORO JUNIOR, Humberto. Celeridade e Efetividade da Prestação Jurisdicional: Insuficiência da reforma das leis processuais. Revista de Processo, São Paulo, ano $30, n^{\circ} 125$, p. 68, jul. 2005.

${ }^{64}$ BARBOSA, Rui. Oração aos Moços. 5. ed., Rio de Janeiro: Fundação Casa Rui Barbosa, 1977, p. 40.

${ }^{65} \mathrm{O}$ dano moral (ou extrapatrimonial), em contraposição ao dano patrimonial, pode ser entendido como "o sofrimento psíquico ou moral, as dores, as angústias e as frustrações infligidas ao ofendido". Para a sua caracterização, a lesão deve ultrapassar o mero dissabor ou aborrecimento típicos da vida em sociedade, pois o prejuízo deve ser extraordinário, molestando "gravemente a alma humana, ferindo-Ihe gravemente os valores fundamentais inerentes à sua personalidade ou reconhecidos pela sociedade em que está integrado". Exatamente pelo seu caráter extrapatrimonial, a reparação do dano moral, prevista no art. $5^{\circ}, \mathrm{V}$ e X, da CRFB e no art. 12 do Código Civil, "se faz através de uma compensação" (geralmente financeira), e não de um ressarcimento. (CAHALI, Yussef Said. Dano Moral. 3. ed., São Paulo: Revista dos Tribunais, 2005, p. 20-44).

${ }^{66}$ Supremo Tribunal Federal, Habeas Corpus (HC) n ${ }^{\circ}$ 91.408, Relator Ministro Eros Grau, Segunda Turma, julgado em 14.08.2007, publicado em 26.10.2007, trechos do voto do Ministro Eros Grau.
} 
não pode o Estado se escusar do cumprimento do art. $5^{\circ}$, LXXVIII, da CRFB sob o argumento do alto volume de demandas, "já que se acha constitucionalmente obrigado a aparelhar o serviço público de modo a cumprir, e fazer cumprir, todos os direitos fundamentais, inclusive o de garantir o acesso à justiça, dentro dos parâmetros do devido processo legal". ${ }^{67}$ Como bem ressalta Luiz Guilherme Marinoni, "talvez falte vontade política para a redução da demora processual". ${ }^{68}$

A fim de ilustrar "a lentidão alarmante do funcionamento dos órgãos da justiça", ${ }^{69}$ é possível colacionar dados estatísticos coletados pelo Supremo Tribunal Federal (STF). O STF possuía, em 28.12.2012, um numeroso acervo de 66.864 processos. Todavia, deste total, 62.313 processos (ou seja, aproximadamente 93\%) se encontravam localizados em setores internos daquele Tribunal, o que demonstra um altíssimo índice de processos aguardando decisão no gabinete dos Ministros - o que é compreensível ante o expressivo número de demandas - ou, em grande parte das vezes, parados nos cartórios e secretarias judiciárias, pendentes de efetiva movimentação. ${ }^{70}$

De fato, talvez o grande desafio para imprimir maior efetividade à tutela jurisdicional seja a redução do chamado tempo morto dos processos, o qual retrata um longo espaço temporal de "completa inatividade procedimental", ${ }^{71}$ geralmente quando os autos ficam estagnados, sem movimentação, nas secretarias e cartórios judiciários. ${ }^{72}$

Também o Conselho Nacional de Justiça $(\mathrm{CNJ})$, por meio do portal "Justiça em Números - Indicadores do Poder Judiciário", possui dados estatísticos interessantes. A título exemplificativo, cite-se que na Justiça Estadual, no ano de 2011, houve um aumento da quantidade de processos baixados em relação aos anos anteriores na ordem de 6,9\%, assim como uma redução da taxa de congestionamento em 0,52\%. Contudo, houve um aumento de $4 \%$ do número de processos em andamento, com uma respectiva diminuição em $0,6 \%$ da quantidade de processos que foram julgados.

\footnotetext{
67 THEODORO JUNIOR, Humberto. Direito Fundamental à Duração Razoável do Processo. Disponível em: http://www.anima-opet.com.br/segunda_edicao/Humberto_Theodoro_Junior.pdf. Acesso em: 25 jun. 2013.

${ }^{68}$ MARINONI, Luiz Guilherme. Novas Linhas do Processo Civil. 2. ed., São Paulo: Malheiros, 1996, p. 29.

${ }^{69}$ TUCCI, José Rogério Cruz e. Tempo e Processo: Uma análise empírica das repercussões do tempo na fenomenologia processual (civil e penal). São Paulo: Revista dos Tribunais, 1998, p. 16.

${ }^{70}$ Disponível em: http://www.stf.jus.br/arquivo/cms/publicacaoBOInternet/anexo/acervoquadros.pdf. Acesso em: 28 dez. 2012.

${ }^{71}$ DIAS, Ronaldo Brêtas de Carvalho. Processo Constitucional e Estado Democrático de Direito. Belo Horizonte: Del Rey, 2010, p. 154.

72 THEODORO JUNIOR, Humberto. Constituição e Processo: Desafios constitucionais da reforma do processo civil no Brasil. In: MACHADO, Felipe Daniel Amorim; CATTONI DE OLIVEIRA, Marcelo Andrade (Coord.). Constituição e Processo: a contribuição do processo ao constitucionalismo democrático brasileiro. Belo Horizonte: Del Rey, 2009, p. 250.
} 
Já na Justiça Federal, o total de processos baixados em 2011 foi superior em $1 \%$ ao total de casos novos, atingindo o montante de três milhões de processos julgados. Todavia, a taxa de congestionamento de $70,6 \%$ foi a maior dos últimos três anos, tendo ainda havido um aumento de 2,7\% do número de processos pendentes de julgamento. ${ }^{73}$

É claro que tais números, por si só, não são suficientes para afirmar o grau de ineficiência do serviço público jurisdicional. ${ }^{74}$ Porém, é certo que a coleta e a análise de dados estatísticos são imprescindíveis para se traçar um diagnóstico mais fidedigno acerca dos problemas advindos da crise judiciária. ${ }^{75} \mathrm{E}$ o que se percebe é que o Judiciário brasileiro ainda não está preparado para enfrentar uma litigiosidade de massa típica do capitalismo, o que resulta em um alto grau de morosidade processual. ${ }^{16}$

Nesse contexto, em determinadas hipóteses, a excessiva lentidão na tramitação dos processos judiciais, aliada à intolerável demora do Judiciário em fornecer a resolução do caso concreto levado a juízo, pode configurar um fato causador de dano moral em desfavor do jurisdicionado.

É óbvio que não estamos dizendo que em qualquer hipótese de demora processual haverá a configuração de lesão psíquica $^{77}$ ao jurisdicionado. É bom ressaltar, apenas em casos excepcionais e devidamente circunstanciados, abrir-se-á a possibilidade de o jurisdicionado pleitear a condenação do Poder Público a indenizá-lo em virtude da má prestação do serviço público jurisdicional, até para que se evite eventual enriquecimento ilícito daquele que se julga lesado.

\footnotetext{
${ }^{73}$ Disponível em: http://www.cnj.jus.br/programas-de-a-a-z/eficiencia-modernizacao-e-transparencia/ pj-justica-em-numeros/relatorios. Acesso em: 28 dez. 2012.

${ }^{74}$ A jurisdição é espécie do gênero serviço público e, como tal, se submete aos princípios da eficiência e da economicidade, a partir de uma gestão profissionalizada. (ANDRADE, Érico. O Mandado de Segurança: A busca da verdadeira especialidade (proposta de releitura à luz da efetividade do processo). Rio de Janeiro: Lumen Juris, 2010, p. 167; FERREIRA, Simone Rodrigues. A Efetividade do Direito Fundamental à Razoável Duração do Processo. Revista IOB de Direito Civil e Processual Civil, Porto Alegre, v. 9, nº 53, p. 141-142, maio/jun. 2008). Nesse viés, a própria Constituição, no art. 93, XIII, prima pela eficiência da prestação do serviço público jurisdicional, ao prever que "o número de juízes na unidade jurisdicional será proporcional à efetiva demanda judicial e à respectiva população".

${ }^{75}$ MOREIRA, José Carlos Barbosa. Temas de Direito Processual: nona série. São Paulo: Saraiva, 2007, p. 36-37.

${ }^{76}$ JAYME, Fernando Gonzaga. Os Problemas da Efetiva garantia de Proteção Judicial perante o Poder Judiciário Brasileiro. In: JAYME, Fernando Gonzaga; FARIA, Juliana Cordeiro de; LAUAR, Maira Terra (Coord.). Processo Civil - Novas Tendências: Estudos em homenagem ao Professor Humberto Theodoro Júnior. Belo Horizonte: Del Rey, 2008, p. 239.

77 A lesão psíquica é aquela que atinge a "esfera da subjetividade, ou do plano valorativo da pessoa na sociedade, em que repercute o fato violador, havendo-se como tais aqueles que atingem os aspectos mais íntimos da personalidade humana (o da intimidade e da consideração pessoal), ou o da própria valoração da pessoa no meio em que vive e atua (o da reputação ou da consideração social)". (BITTAR, Carlos Alberto. Reparação Civil por Danos Morais. São Paulo: Revista dos Tribunais, 1992, p. 41).
} 
A bem da verdade, a definição da razoável duração do processo "é um problema que somente pode ser enfrentado e dirimido em face de dados concretos, os quais variam enormemente de um processo para outro". ${ }^{78}$ Nesse contexto, a Corte Europeia dos Direitos do Homem (também conhecida como Tribunal dos Direitos do Homem de Estrasburgo), a fim de fixar parâmetros mais precisos, enumerou três critérios para delimitar o tempo razoável do processo, a ser aferidos de acordo com as peculiaridades do caso concreto, a saber: a) complexidade da matéria; b) comportamento das partes e de seus procuradores; c) atuação do órgão jurisdicional.

Nessa trilha, a complexidade das questões de fato e de direito envolvidas na demanda pode justificar a realização de uma instrução probatória mais minuciosa que implique maior duração temporal do processo. De modo semelhante, a apresentação pelas partes de incidentes processuais impertinentes pode acarretar dilação processual indevida - o que não impede, é bom frisar, a interposição de recursos ou a apresentação de alegações dentro da esfera do legítimo exercício da ampla defesa. Outrossim, a própria inércia do órgão jurisdicional em proferir despachos e decisões, ou a paralisação de processos em cartórios e secretarias judiciárias, também impedem que os processos sejam impulsionados de modo tempestivo.

Da análise dos parâmetros estabelecidos pela Corte Europeia dos Direitos do Homem, percebe-se que, se o tumulto da marcha processual foi causado pela complexidade da matéria em discussão ou pelo comportamento procrastinatório das próprias partes, não será possível imputar ao Judiciário a responsabilidade pela demora na tramitação do processo.

É que, como salienta Marco Félix Jobim, "somente o Estado ser considerado o único responsável pela intempestividade processual não é um caminho que visa a combater a duração não razoável do processo, mas, consequentemente, apenas agravá-la". Isso porque, para que seja atingido o objetivo de coibir a ilegítima demora na marcha processual, é preciso "criar mecanismos de punição a toda e qualquer pessoa que, injustificadamente, traga entrave à prestação jurisdicional", para que seja evitada uma multiplicação de processos (como ocorrido na Itália) que implicará, apenas, em mais dilação do tempo de espera do jurisdicionado, de modo antagônico ao próprio objetivo de atribuição de maior tempestividade à tutela jurisdicional. ${ }^{79}$

\footnotetext{
78 THEODORO JUNIOR, Humberto. Direito Fundamental à Duração Razoável do Processo. Disponível em: http://www.anima-opet.com.br/segunda_edicao/Humberto_Theodoro_Junior.pdf. Acesso em: 17 dez. 2012.

${ }^{79}$ JOBIM, Marco Félix. A Responsabilidade Civil do Estado em Decorrência da Intempestividade Processual. Revista Jurídica, Porto Alegre, v. 59, nº 409, p. 56-66, nov. 2011. A multiplicação de processos ocorrida na Itália é bem ilustrada por Elaine Nassif. Segundo a autora, desde a edição da já citada Legge Pinto, em 2001, já foram registrados aproximadamente 40 mil processos em que se pleiteia indenização por danos morais em virtude de intempestividade processual, sendo que, até 2008, o Estado Italiano havia arcado com 118 milhões de euros a título de indenizações. (NASSIF, Elaine. Sobre a Duração Razoável do Processo. Disponível em: http://www.prt3.mpt.gov.br/ imprensa/?p=1657.\%20Acesso\%20em:\%2016\%20mar.\%202011. Acesso em: 04 fev. 2013).
} 
Por outro lado, se a delonga excessiva do procedimento é consequência direta e inafastável da comprovada inércia do juiz e de seus auxiliares no cumprimento de prazos legais, ou na própria falta de controle judicial do comportamento das partes e da realização de provas inúteis (arts. 14, V e 130, do CPC), tornar-se-á possível, em tese, a atribuição de responsabilidade ao Judiciário pela infringência ao direito fundamental à duração razoável do processo (art. 50, LXXVIII, da CRFB) e ao art. 35, II e III, da LOMAN. Esse posicionamento encontra respaldo na doutrina jurídica:

Ora, se o Poder Judiciário está em atraso com seu jurisdicionado, é o mesmo que dizer que o Estado está em falta grave com seu cidadão, e, se isso de fato ocorre, deve ele indenizar aquele que se sentir prejudicado pela intempestividade processual, provando, por óbvio, seu prejuízo, que pode ser patrimonial ou extrapatrimonial. ${ }^{80}$

O direito à indenização por danos oriundos da prestação jurisdicional intempestiva tem sido reconhecido e aplicado pelo mundo afora, conforme pôde se depreender da prática da Corte Europeia de Direitos Humanos. Por mais que se tenha caráter eminentemente paliativo, e não estrutural, a reparação civil acaba por ser um instrumento útil para minimizar os efeitos da demora dos processos sobre a vida dos indivíduos. ${ }^{81}$

De fato, o dever de indenização do Estado pela intempestividade processual não tem a pretensão de resolver os problemas administrativos e estruturais que perpassam a crise judiciária. Diferentemente, a imputação da responsabilidade civil ao ente público visa a concretizar um direito fundamental, como "meio de se assegurar ao cidadão o direito à jurisdição, à prestação jurisdicional em tempo razoável ou sem dilações indevidas". ${ }^{82}$ Assim, a violação ao direito fundamental à razoável duração do processo pode ser enquadrada "em uma das hipóteses de responsabilidade do Estado". ${ }^{3}$

É cediço que a imputação de responsabilidade civil ao Estado (art. 37, $\S 6^{\circ}$, da CRFB) demanda o preenchimento de determinados requisitos, a saber: a) o fato administrativo, "assim considerado como qualquer forma de conduta, comissiva ou omissiva, legítima ou ilegítima, singular ou coletiva, atribuída ao Poder Público"; b) o dano, já que "não há falar em responsabilidade civil sem que a conduta haja provocado um dano", ou seja, "se o dito lesado não prova que a conduta estatal lhe causou prejuízo, nenhuma reparação terá a postular"; c) o nexo causal (ou relação de causalidade) entre o fato administrativo e o dano, significando que "se o dano decorre de fato que, de modo algum,

\footnotetext{
80 JOBIM, Marco Félix. A Responsabilidade Civil do Estado em Decorrência da Intempestividade Processual. Revista Jurídica, Porto Alegre, v. 59, nº 409, p. 57, nov. 2011.

${ }^{81}$ RAMOS, Carlos Henrique. Processo Civil e o Princípio da Duração Razoável do Processo. Curitiba: Juruá, 2008, p. 104.

${ }^{82}$ ANNONI, Danielle. Responsabilidade do Estado pela não Duração Razoável do Processo. Curitiba: Juruá, 2008, p. 152.

${ }^{83}$ NICOLITT, André Luiz. A Duração Razoável do Processo. Rio de Janeiro: Lumen Juris, 2006, p. 114.
} 
pode ser imputado à Administração, não se poderá imputar responsabilidade civil a esta; inexistindo o fato administrativo, não haverá por consequência, o nexo causal", motivo pelo qual "não se pode responsabilizar o Estado por todos os danos sofridos pelos indivíduos". ${ }^{84}$

$\mathrm{Na}$ hipótese, a discussão se refere à responsabilidade civil do Estado, por força de ilícita lentidão na tramitação de processo judicial, causada por inércia no impulso oficial e no julgamento da demanda. Portanto, tratando-se de ato omissivo que revela falha na prestação jurisdicional, é necessária, também, a comprovação da culpa (em suas modalidades de negligência, imperícia ou imprudência) ou do dolo, com base na aplicação analógica do art. 927, parágrafo único, do Código Civil. ${ }^{85}$

Sendo assim, apenas caso estejam devidamente apurados, no caso concreto, os requisitos para a atribuição de responsabilidade civil ao Estado, tornar-se-á possível ao jurisdicionado deduzir judicialmente a pretensão de reparação moral dos danos que lhe foram causados em virtude da lentidão excessiva na resolução da sua contenda.

No ponto, é preciso frisar que o dano moral, para que seja caracterizado, deve estar baseado em uma circunstância de evidente intempestividade processual, isto é, uma situação na qual houve uma intolerável e excessiva demora na tramitação ou na resolução do caso concreto em virtude de falha culposa ou dolosa na prestação jurisdicional. Por via de consequência, tanto o processo intempestivo (fora de um prazo razoável) como o processo moroso (excessivamente lento) são capazes de ensejar a responsabilidade civil do Estado.

Em resumo, é preciso que o jurisdicionado comprove no caso concreto:

a) que houve uma situação de ilegítima ineficiência na prestação do serviço público jurisdicional (art. 37, caput, da CRFB), consistente na violação do seu direito fundamental à razoável duração do processo em virtude de uma excessiva e intolerável lentidão na tramitação de seu processo judicial (art. $5^{\circ}$, LXXVIII, da CRFB);

b) que a lentidão na resolução de sua demanda implicou danos à sua esfera moral, os quais devem ser devidamente comprovados e circunstanciados em face das peculiaridades do caso concreto;

c) que o dano moral foi causado, direta e unicamente, pela falha na prestação jurisdicional, preservadas as hipóteses de exclusão da imputação de responsabilidade civil ao Estado (v.g., caso fortuito, força maior e culpa exclusiva de terceiro);

\footnotetext{
${ }^{84}$ CARVALHO FILHO, José dos Santos. Manual de Direito Administrativo. 17. ed., Rio de Janeiro: Lumen luris, 2007, p. 482.

${ }^{85} \mathrm{Em}$ sentido semelhante, Paulo Hoffman aduz que o Estado é responsável pela "exagerada duração do processo, motivada por dolo ou culpa do juiz, bem como por ineficiência da estrutura do Poder Judiciário, devendo indenizar o jurisdicionado prejudicado (...)." (HOFFMAN, Paulo. Razoável Duração do Processo. São Paulo: Quartier Latin, 2006, p. 99-100).
} 
d) que a demora processual e a má prestação do serviço público jurisdicional decorreram de imprudência, imperícia, negligência ou dolo dos órgãos, membros e auxiliares judiciários.

Nesse cenário, os Tribunais, ainda que de modo incipiente, vêm se inclinando para a possibilidade de condenação do Estado à reparação dos danos causados em virtude da ilícita demora no andamento de processos judiciais, sobretudo quando a procrastinação injustificada ocorre por ilegítima inércia do órgão jurisdicional.

A Corte Europeia dos Direitos do Homem, em significativo julgamento ocorrido em 25 de junho de 1987, condenou o Estado da Itália a indenizar um jurisdicionado em razão dos danos materiais e morais sofridos em decorrência "do estado de prolongada ansiedade pelo êxito da demanda". ${ }^{86}$

Embora ainda raras, também a jurisprudência brasileira possui decisões em sentido semelhante. Cite-se, por exemplo, acórdão proferido pelo Tribunal de Justiça do Estado do Rio Grande do Sul, o qual, conhecido por sua atuação de vanguarda, condenou o Município de Passo Fundo à reparação de dano moral causado por atraso injustificado na conclusão de sindicância administrativa instaurada em desfavor de servidor público municipal:

Trechos do voto do Desembargador Carlos Alberto Alvaro de Oliveira.

(...). Maior desenvolvimento requer a alegação de excesso de prazo no desenvolvimento da sindicância e do inquérito administrativo que se seguiu. Segundo entendo, o prolongamento excessivo desses procedimentos pode vir a causar, em tese, angústia e sofrimento moral ao acusado, de molde a determinar a reparação do dano moral, de conformidade com a garantia constitucional assegurada no art. $5^{\circ}$, inciso X, da Constituição da República, mormente porque esta instituiu como princípio basilar 0 respeito à dignidade humana (art. $1^{\circ}$, inciso III). (...). Esse atraso inexplicável da conclusão dos trabalhos por quase 1 ano e meio (período compreendido entre 11.12 .1996 e 15.05.1998) prolongou sem justificativa a angústia e a incerteza do autor, que naturalmente almejava o fim do procedimento administrativo, visto que inocente das acusações, como ao final veio a ser reconhecido. Essa dor moral impõe-se reparada, responsabilizando o Município demandado, que por negligência no desempenho de suas funções agravou a situação aflitiva do autor. ${ }^{87}$

Também no Superior Tribunal de Justiça é possível encontrar orientação segundo a qual "A demora injustificada da Administração Pública para apreciar

\footnotetext{
${ }^{86}$ Íntegra da decisão em TUCCI, José Rogério Cruz e. Duração Razoável do Processo (art. 5º, LXXVIII, da Constituição Federal). In: JAYME, Fernando Gonzaga; FARIA, Juliana Cordeiro de; LAUAR, Maira Terra (Coord.). Processo Civil - Novas Tendências: Estudos em homenagem ao Professor Humberto Theodoro Júnior. Belo Horizonte: Del Rey, 2008, p. 438-442.

${ }^{87}$ Tribunal de Justiça do Rio Grande do Sul (TJRS), Apelação Cível no 70006474233, Sexta Câmara Cível, Relator Desembargador Carlos Alberto Alvaro de Oliveira, julgado em 15.09.2004.
} 
pedido de aposentadoria, obrigando o servidor a continuar exercendo compulsoriamente suas funções, gera o dever de indenizar". ${ }^{88}$

De fato, a nosso ver, a violação ao direito fundamental à razoável duração do processo é capaz de produzir, em determinadas situações, abalos psíquicos aos jurisdicionados passíveis de configuração de dano moral. Nesses casos, ao Estado poderá ser atribuída a responsabilidade pela ineficiência do serviço público jurisdicional, para fins de reparação de eventuais danos causados aos jurisdicionados.

A indenização, além disso, pode produzir o efeito de "incentivar o Judiciário e seus integrantes a resolver mais rápido as causas" e de "incentivar o próprio legislador a criar novos mecanismos legais de simplificação processual". ${ }^{90}$ Aliás, até mesmo para a parte derrotada, "o possível e natural inconformismo é, sem dúvida, mais tênue quando a luta processual não se prolonga durante muito tempo". ${ }^{91}$

$\mathrm{Na}$ verdade, o Direito, como "generalização de expectativas", ${ }^{92}$ cria na pessoa humana um estado legítimo de espera voltado à resolução de seu problema em um lapso de tempo tolerável. Ainda que o tempo seja um conceito aberto e contingencial, ele fornece uma "interpretação social da realidade em relação à diferença entre passado e futuro" ${ }^{13}$ que atribui ao jurisdicionado uma situação de espera referente à alteração de seu status quo ante, a qual, se frustrada, pode gerar dano moral.

O Direito, é certo, não pode fazer com que "o tempo saia de seus eixos". Analogicamente, o processo não deve se converter em um mecanismo de aceleração incondicional de mudanças instáveis, efêmeras e aleatórias, como se o ritmo da urgência ditasse os parâmetros das relações jurídicas. ${ }^{94}$

\footnotetext{
${ }^{88}$ Superior Tribunal de Justiça, Recurso Especial (REsp) no 1052461/MS, Primeira Turma, Rel. Ministro Teori Albino Zavascki, julgado em 02.04.2009, DJe 16.04.2009.

${ }^{89}$ BEZERRA, Márcia Fernandes. O Direito à Razoável Duração do Processo e a Responsabilidade do Estado pela demora na Outorga da Prestação Jurisdicional. In: WAMBIER, Teresa Arruda Alvim et al. (Coord.) Reforma do Judiciário. São Paulo: Revista dos Tribunais, 2005, p. 478; DIAS, Ronaldo Brêtas de Carvalho. Responsabilidade do Estado pela Função Jurisdicional. Belo Horizonte: Del Rey, 2004, p. 194-203.

${ }^{90}$ ANDRADE, Érico. O Mandado de Segurança: A busca da verdadeira especialidade (proposta de releitura à luz da efetividade do processo). Rio de Janeiro: Lumen Juris, 2010, p. 109.

${ }_{91}$ TUCCI, José Rogério Cruz e. Sobre a Duração Razoável do Processo na Europa Comunitária. In: JAYME, Fernando Gonzaga; FARIA, Juliana Cordeiro de; LAUAR, Maira Terra (Coord.). Processo Civil - Novas Tendências: Homenagem ao Ministro Sálvio de Figueiredo Teixeira. Belo Horizonte: Del Rey, 2011, p. 434.

${ }^{2}$ ARAUJO PINTO, Cristiano Paixão. Modernidade, Tempo e Direito. Belo Horizonte: Del Rey, 2002, p. 199-209.

${ }_{93}$ LUHMANN, Niklas. The Future cannot Begin. In: LUHMANN, Niklas. The Differentiation of Society. Trad. Stephen Holmes e Charles Larmore New York: Columbia University Press, 1982 apud ARAUJO PINTO, Cristiano Paixão. Modernidade, Tempo e Direito. Belo Horizonte: Del Rey, 2002, p. 299.

${ }^{94}$ OST, François. O Tempo do Direito. Tradução de Élcio Fernandes. Bauru: Edusc, 2005, p. $330-341$.
} 
Diferentemente, o processo tem que atuar como instrumento de conformação da lei às particularidades do caso concreto e, para isso, deve demorar o tempo razoavelmente necessário à concretização dos direitos fundamentais, das garantias processuais e do direito material em discussão, sob pena de infligir ao jurisdicionado angústia e insatisfação. ${ }^{95}$

É preciso encarar o fato de que um processo judicial pode retratar esperanças de cidadãos que buscam, no Judiciário, a resolução de frustrações que tiveram no convívio social. Nessa linha de raciocínio, processos que duram quase uma eternidade colidem com a própria brevidade da vida dos jurisdicionados.

Portanto, uma prestação jurisdicional que se desenvolva em um lapso temporal razoável, compatível com a natureza do litígio e sem dilações indevidas, tem o condão de melhor implicar satisfação às partes, conjugando a efetividade da tutela jurisdicional com o acesso a uma ordem jurídica justa.

\section{CONSIDERAÇÕES FINAIS}

A efetividade do processo e o acesso a uma ordem jurídica justa requerem que o processo produza resultados práticos na vida social, os quais permitam que a parte usufrua o bem da vida que Ihe foi reconhecido judicialmente. Para esse objetivo, a tramitação do processo deve obedecer a um lapso de tempo objetivamente aceitável, sem dilações indevidas ou etapas processuais mortas.

O que se combate, portanto, é a intempestividade (e, consequentemente, a morosidade) processual consistente na ilegítima falha na prestação do serviço público jurisdicional. Em outras palavras, a atribuição de responsabilidade civil ao Estado visa a coibir dilações indevidas comumente perpetradas nos cartórios e órgãos jurisdicionais, as quais não se coadunam com o direito fundamental à razoável duração do processo.

Por seu turno, a regular demora na tramitação dos processos, em virtude de instrução probatória ou exercício do direito de defesa compatíveis com a natureza da demanda, é natural sob a perspectiva do acesso à ordem jurídica justa. A efetividade da tutela jurisdicional, logo, pode guardar um razoável prolongamento em decorrência da atividade dialética das partes, o que não se confunde, é bom repetir, com abusos na condução da marcha processual.

Nesse contexto, a excessiva e intolerável demora no julgamento equivale à própria negativa de prestação jurisdicional. A jurisdição, como espécie de serviço público, submete-se à observância dos princípios da legalidade e da eficiência (art. 37, caput, da CRFB). Assim, se comprovados os requisitos

\footnotetext{
95 "A morosidade da Justiça é a causa maior de seu descrédito pelo jurisdicionado: causa angústia, insatisfação" (trecos da sentença proferida no processo n 89.0017372-3, na $7^{\text {a }}$ Vara Federal de São Paulo, em que a União Federal foi condenada a pagar indenização equivalente a 150 salários mínimos à parte, a título de danos morais, em decorrência da morosidade e da longa tramitação processual por mais de 20 anos até a obtenção de uma sentença definitiva. Cf.: ANNONI, Danielle. Responsabilidade do Estado pela não Duração Razoável do Processo. Curitiba: Juruá, 2008, p. 137).
} 
no caso concreto, é possível a atribuição de responsabilidade civil ao Estado para fins de reparação do dano moral causado ao jurisdicionado, em virtude de ilegítima e intolerável intempestividade processual que implica, diretamente, transgressão à eficácia plena e à aplicabilidade imediata (art. $5^{\circ}$, $\S 1^{\circ}$, da $\mathrm{CRFB}$ ) do direito fundamental à razoável duração do processo (art. 50, LXXVIII, da CRFB).

\section{REFERÊNCIAS BIBLIOGRÁFICAS}

ANDRADE, Érico. O Mandado de Segurança: a busca da verdadeira especialidade (proposta de releitura à luz da efetividade do processo). Rio de Janeiro: Lumen Juris, 2010.

ANNONI, Danielle. Responsabilidade do Estado pela não Duração Razoável do Processo. Curitiba: Juruá, 2008.

ARRUDA, Samuel Miranda. O Direito Fundamental à Razoável Duração do Processo. Brasília: Brasília Jurídica, 2006.

ASSIS, Araken. Duração Razoável do Processo e Reformas da Lei Processual Civil. Revista Jurídica, Porto Alegre, ano 56, no 372, out. 2008.

BARBOSA, Rui. Oração aos Moços. 5. ed., Rio de Janeiro: Fundação Casa Rui Barbosa, 1977.

BEDAQUE, José Roberto dos Santos. Direito e Processo: Influência do direito material sobre o processo. 5. ed., São Paulo: Malheiros, 2009.

2010.

. Efetividade do Processo e Técnica Processual. 3. ed., São Paulo: Malheiros,

BEZERRA, Márcia Fernandes. O Direito à Razoável Duração do Processo e a Responsabilidade do Estado pela demora na outorga da Prestação Jurisdicional. In: WAMBIER, Teresa Arruda Alvim et al. (Coord.) Reforma do Judiciário. São Paulo: Revista dos Tribunais, 2005.

BITTAR, Carlos Alberto. Reparação Civil por Danos Morais. São Paulo: Revista dos Tribunais, 1992.

CAHALI, Yussef Said. Dano Moral. 3. ed., São Paulo: Revista dos Tribunais, 2005.

CANOTILHO, J. J. Gomes. Direito Constitucional e Teoria da Constituição. Coimbra: Almedina, 2002.

CAPPELLETTI, Mauro. Processo, Ideologias e Sociedade. Tradução de Elício de Cresci Sobrinho. Porto Alegre: Sergio Antonio Fabris, 2008. v. 1.

CAPPELLETTI, Mauro; GARTH, Bryant. Acesso à Justiça. Tradução de Ellen Gracie Northfleet. Porto Alegre: Sergio Antonio Fabris, 1988.

CARVALHO FILHO, José dos Santos. Manual de Direito Administrativo. 17. ed., Rio de Janeiro: Lumen luris, 2007.

CASAGRANDE, Érico Vinícius Prado. Efetividade do Direito e Eficiência do Judiciário. In: TAVARES, Fernando Horta (Coord.). Urgências de Tutela. Curitiba: Juruá, 2007.

COMOGLIO, Luigi Paolo. Etica e Tecnica del 'giusto Processo'. Torino, G. Giappichelli: 2004.

DIAS, Ronaldo Brêtas de Carvalho. As Reformas do Código de Processo Civil e o Processo Constitucional. In: DIAS, Ronaldo Brêtas; NEPOMUCENO, Luciana Diniz (Coord.). Processo Civil Reformado. Belo Horizonte: Del Rey, 2007. 
. Direito à Jurisdição Eficiente e Garantia da Razoável Duração do Processo na Reforma do Judiciário. Revista de Processo, São Paulo, ano 30, nº 128, out. 2005.

$\overline{\text { Del Rey, }} 2010$.

Processo Constitucional e Estado Democrático de Direito. Belo Horizonte: $\overline{\text { Del Rey }}, 2004$.

Responsabilidade do Estado pela Função Jurisdicional. Belo Horizonte:

DIDIER JR., Fredie. Notas sobre a Garantia Constitucional do Acesso à Justiça: O princípio do direito de ação ou da inafastabilidade do Poder Judiciário. Revista de Processo, São Paulo, ano 27, nº 108, out./dez. 2002.

DINAMARCO, Cândido Rangel. A Instrumentalidade do Processo. 14. ed., São Paulo: Malheiros, 2009.

2009.

. Instituições de Direito Processual Civil. 6. ed., v. 1, São Paulo: Malheiros,

FERREIRA, Simone Rodrigues. A Efetividade do Direito Fundamental à Razoável Duração do Processo. Revista $I O B$ de Direito Civil e Processual Civil, Porto Alegre, v. 9, n 53, maio/jun. 2008.

GOMES, Magno Federici; SOUSA, Isabella Saldanha de. A Efetividade do Processo e a Celeridade do Procedimento sob o Enfoque da Teoria Neo-institucionalista. Revista IOB de Direito Civil e Processual Civil, Porto Alegre, v. 9, nº 57, jan./fev. 2009.

GONÇALVES, Aroldo Plínio. Técnica Processual e Teoria do Processo. Rio de Janeiro: Aide, 1992.

HOFFMAN, Paulo. Razoável Duração do Processo. São Paulo: Quartier Latin, 2006.

JAYME, Fernando Gonzaga. Os Problemas da Efetiva Garantia de Proteção Judicial perante o Poder Judiciário Brasileiro. In: JAYME, Fernando Gonzaga; FARIA, Juliana Cordeiro de; LAUAR, Maira Terra (Coord.). Processo Civil - Novas Tendências: Estudos em homenagem ao Professor Humberto Theodoro Júnior. Belo Horizonte: Del Rey, 2008.

JOBIM, Marco Félix. A Responsabilidade Civil do Estado em Decorrência da Intempestividade Processual. Revista Jurídica, Porto Alegre, v. 59, n 409, nov. 2011.

LEAL, Rosemiro Pereira. A Judiciarização do Processo nas últimas Reformas do CPC Brasileiro. In: DIAS, Ronaldo Brêtas; NEPOMUCENO, Luciana Diniz (Coord.). Processo Civil Reformado. Belo Horizonte: Del Rey, 2007.

LLOBREGAT, José Garberí. El Derecho a la Tutela Judicial Efectiva en la Jurisprudencia del Tribunal Constitucional. Barcelona: Bosch, 2008.

LLORENTE, Francisco Rubio. Derechos Fundamentales y Principios Constitucionales: Doctrina jurisprudencial. Barcelona: Ariel, 1995.

MAGALHÃES, Ana Luíza de Carvalho; CÔRTES, Osmar Mendes Paixão. Efetividade da Prestação Jurisdicional: O inciso LXXVIII, do Art. $5^{\circ}$ da Constituição Federal inserido pela EC 45/2004. Revista de Processo, São Paulo, v. 31, nº 138, ago. 2006.

MARINONI, Luiz Guilherme. Da Teoria da Relação Jurídica Processual ao Processo Civil do Estado Constitucional. Revista dos Tribunais, São Paulo, vol. 852, ano 95, out. 2006.

. Direito Fundamental à Duração Razoável do Processo. Revista Jurídica, Porto Alegre, ano 57, nº 379, maio 2009. 
. Efetividade do Processo e Tutela Antecipatória. Revista dos Tribunais, nº 706, São Paulo, 1994.

O Custo e o Tempo do Processo Civil Brasileiro. Revista da Faculdade de

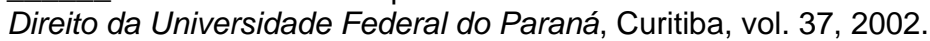

. Novas Linhas do Processo Civil. 2. ed., São Paulo: Malheiros, 1996.

2004.

. Técnica Processual e Tutela dos Direitos. São Paulo: Revista dos Tribunais,

MELO, Gustavo de Medeiros. O Acesso adequado à Justiça na Perspectiva do Justo Processo. Disponível em: http://www.ibds.com.br/artigos/OACESSOADEQUADO aJUSTICANAPERSPECTIVADOJUSTOPROCESSO.pdf. Acesso em: 27 dez. 2012.

MOREIRA, José Carlos Barbosa. Temas de Direito Processual: nona série. São Paulo: Saraiva, 2007.

. Temas de Direito Processual: sexta série. São Paulo: Saraiva, 1991.

NASSIF, Elaine. Sobre a Duração Razoável do Processo. Disponível em: http://www.prt3.mpt.gov.br/imprensa/?p=1657.\%20Acesso\%20em:\%2016\%20mar.\%20 2011. Acesso em: 04 fev. 2013.

NICOLITT, André Luiz. A Duração Razoável do Processo. Rio de Janeiro: Lumen Juris, 2006.

OLIVEIRA, Carlos Alberto Alvaro de. Do Formalismo no Processo Civil. 2. ed., São Paulo: Saraiva, 2003.

. Efetividade e Tutela Jurisdicional. In: MARINONI, Luiz Guilherme (Coord.). Estudos de Direito Processual Civil: Homenagem ao professor Egas Dirceu Moniz de Aragão. São Paulo: Revista dos Tribunais, 2006.

. Teoria e Prática da Tutela Jurisdicional. Rio de Janeiro: Forense, 2008.

OST, François. O Tempo do Direito. Tradução de Élcio Fernandes. Bauru: Edusc, 2005. RAMOS, Carlos Henrique. Processo Civil e o Princípio da Duração Razoável do Processo. Curitiba: Juruá, 2008.

REIS, Marcelo Terra. Tempestividade da Prestação Jurisdicional como Direito Fundamental. In: TEIXEIRA, Anderson Vichinkeski; LONGO, Luís Antônio (Coord.). A Constitucionalização do Direito. Porto Alegre: Sérgio Antônio Fabris, 2008.

ROCHA, Cesar Asfor. A Luta pela Efetividade da Jurisdição. São Paulo: Revista dos Tribunais, 2008.

RODRIGUES, Clóvis Fedrizzi. Celeridade Processual versus Segurança Jurídica. Revista de Processo, São Paulo, ano 30, nº 120, fev. 2005.

. Direito Fundamental à Duração Razoável do Processo. Revista IOB de Direito Civil e Processual Civil, ano XI, nº 63, jan./fev. 2010.

SILVA, José Afonso da. Comentário Contextual à Constituição. São Paulo: Malheiros, 2006.

SOUSA, Michele Faria de. O Procedimento dos Juizados Especiais Cíveis e Efetividade do Processo. In: TAVARES, Fernando Horta (Coord.). Urgências de Tutela. Curitiba: Juruá, 2007.

THEODORO JUNIOR, Humberto. Celeridade e Efetividade da Prestação Jurisdicional: Insuficiência da reforma das leis processuais. Revista de Processo, São Paulo, ano 30, $n^{\circ} 125$, jul. 2005. 
. Constituição e Processo: Desafios constitucionais da reforma do processo civil no Brasil. In: MACHADO, Felipe Daniel Amorim; CATTONI DE OLIVEIRA, Marcelo Andrade (Coord.). Constituição e Processo: A contribuição do processo ao constitucionalismo democrático brasileiro. Belo Horizonte: Del Rey, 2009.

Curso de Direito Processual Civil: Teoria geral do direito processual civil e processo de conhecimento. 43. ed., v. I, Rio de Janeiro: Forense, 2005.

. Direito Fundamental à Duração Razoável do Processo. Disponível em: http://www.anima-opet.com.br/segunda_edicao/Humberto_Theodoro_Junior.pdf. Acesso em: 17 dez. 2012.

Janeiro, 1999.

O Processo Civil Brasileiro no Limiar do Novo Século. Forense: Rio de

TUCCI, José Rogério Cruz e. Duração Razoável do Processo (art. 5, LXXVIII, da Constituição Federal). In: JAYME, Fernando Gonzaga; FARIA, Juliana Cordeiro de; LAUAR, Maira Terra (Coord.). Processo Civil - Novas Tendências: Estudos em homenagem ao Professor Humberto Theodoro Júnior. Belo Horizonte: Del Rey, 2008.

. Garantias Constitucionais da Duração Razoável e da Economia Processual no Projeto do Código de Processo Civil. Revista de Processo, São Paulo, ano 36, no 192, fev. 2011.

. Sobre a Duração Razoável do Processo na Europa Comunitária. In: JAYME, Fernando Gonzaga; FARIA, Juliana Cordeiro de; LAUAR, Maira Terra (Coord.). Processo Civil - Novas Tendências: Homenagem ao Ministro Sálvio de Figueiredo Teixeira. Belo Horizonte: Del Rey, 2011.

Tempo e Processo: Uma análise empírica das repercussões do tempo na fenomenologia processual (civil e penal). São Paulo: Revista dos Tribunais, 1998.

TUCCI, Rogério Lauria; TUCCI, José Rogério Cruz e. Constituição de 1988 e Processo: Regramentos e garantias constitucionais do processo. São Paulo: Saraiva, 1989.

WAMBIER, Teresa Arruda Alvim. Aspectos Polêmicos da Antecipação da Tutela. São Paulo: Revista dos Tribunais, 1997.

WAMBIER, Luiz Rodrigues; WAMBIER, Teresa Arruda Alvim; MEDINA, José Miguel Garcia. Breves Comentários à Nova Sistemática Processual Civil. 3. ed., São Paulo: Revista dos Tribunais, 2005.

WATANABE, Kazuo. Da Cognição no Processo Civil. 2. ed., Campinas: Bookseller, 2000.

. Participação e Processo. São Paulo: Revista dos Tribunais, 1988.

WELSCH, Gisele Mazzoni. A Razoável Duração do Processo (art. 5, LXXVIII, da CF/88) como Garantia Constitucional. In: MOLINARO, Carlos Alberto; MILHORANZA, Mariângela Guerreiro; PORTO, Sérgio Gilberto (Coord.). Constituição, Jurisdição e Processo: Estudos em homenagem aos 55 anos da Revista Jurídica. Porto Alegre: Notadez, 2007.

ZAVASCKI, Teori Albino. Antecipação da Tutela. 4. ed., São Paulo: Saraiva, 2005. 